\title{
A Study on the Cytology and Life-history of Cladophora uberrima Lambert. from Ranchi, India
}

\author{
J. P. Sinha and S. Ahmed \\ University Department of Botany, Ranchi University, \\ Ranchi, Bihar, India
}

Received June 4, 1971

Studies on the life-history based upon cytological characters have been made earlier by T'Serclaes (1922), Cook and Price (1928), Foÿn (1929 and 1934), Czempyrek (1930), List (1930), Higgins (1930), Geitler (1936), Bliding (1936), Schüssnig (1928, 1930, 1938, 1951-54 and 1955), Sinha (1958, 1963, 1965, and 1968), Balakrishnan (1961), Noor (1965) and Verma (1969) in various species of Cladophora. Sinha's $(1963,1965$, and 1968) observations made in this context are the most recent notable additions towards the better understanding of this genus.

The present paper is devoted to a study on the life-history based upon cytological features on a fresh-water species of Cladophra viz. C. uberrima Lambert, collected from Ranchi in the month of July, 1970. The present meiotic chromosomal count $(n=6)$ determined in this species is the first report which has not been made so far in any of the species of Cladophora from India.

\section{Material and methods}

The material has been collected in the month of July, 1970 from Khajuria Talab, Ranchi, which was found growing attached to the shells of Pila globosa. The material was brought in the laboratory and was thoroughly washed. Finally, it was inoculated in modified Godward's (1942) culture solution fortified with $10 \%$ soil extract. The growth of the alga was luxuriant in 12 hours light and 12 hours dark. A few filaments were fixed in 1:1 aceto-alcohol from culture solution. After keeping 24 hours in the fixative, the material was thoroughly washed and nitric acid vapour was used for softening of the cell-walls and for better spreading of the chromosomes.

Godward's (1948) iron-alum acetocarmine technique was employed throughout the present investigation.

\section{Morphological observations}

The plant measures 1 to $1.2 \mathrm{~cm}$ in length (Fig. 1a) and is attached below by short irregular rhizoids (Fig. 1b). The filaments of the alga is grass-green in colour. Cells in the principal filaments are $32 \mu$ to $60 \mu$ broad and 5 to 10 times longer than broad (Fig. 1b). Collins (1928) has reported this plant up to $1 \mathrm{~cm}$ in length and the cells from $30 \mu$ to $50 \mu$ rarely $60 \mu$ broad being 3 to 10 times longer than broad 
in the principal filaments where as Verma (1969) has reported this plant up to $1.25 \mathrm{~cm}$ in length and the cells from $30 \mu$ to $50 \mu$ broad being 3 to 9 times longer than broad in the principal filaments.

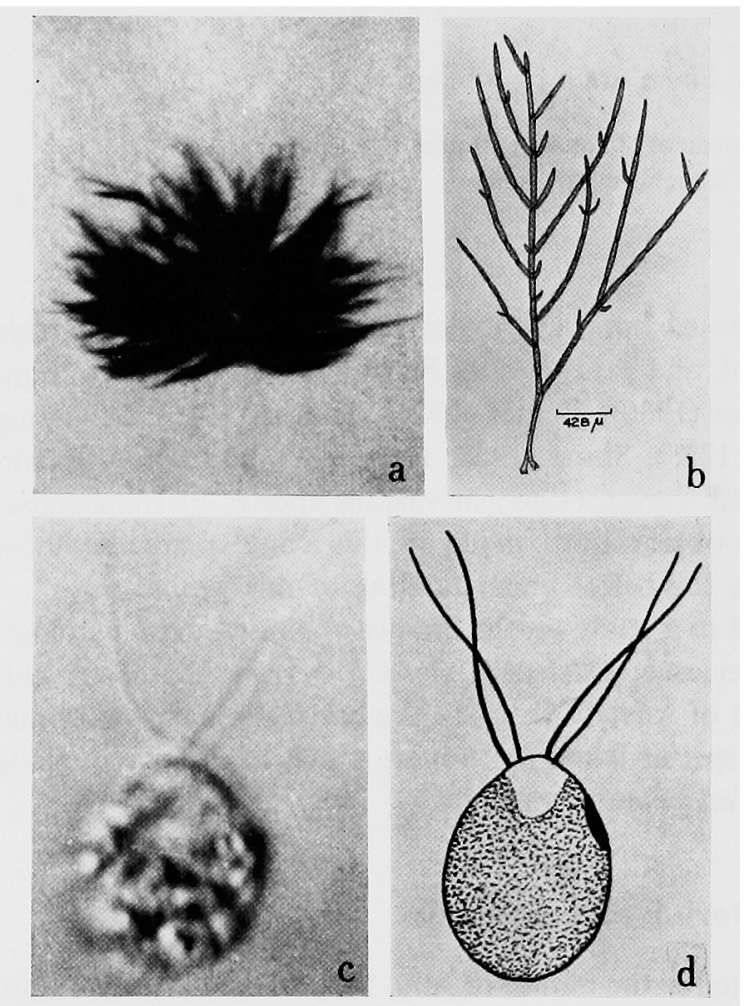

Fig. 1. a, habit of the young plant. $\times 2.8$. b, camera lucida sketch of a complete plant showing branched rhizoid and mode of branching. c, photomicrograph of a quadriflagellate zoospore. $\times 2875$. d, outline drawing of

Fig. 1c.

Branches are solitary, alternate or opposite but in the latter case one is welldeveloped and sometimes become rebranched where as the other remains singlecelled (Fig. 1b). Ramuli are straight or curved, $18 \mu$ to $23 \mu$ broad and 5 to 9 times longer than broad. Collins (1928) has reported the cells from $15 \mu$ to $20 \mu$ broad and 5 to 10 times longer than broad in the ramuli where as Verma (1969) has reported the cells from $18 \mu$ to $25 \mu$ broad and 6 to 11 times longer than broad.

\section{Cytological observations}

a. Mitosis: The mitotic division follows a normal course. The interphase nucleus is spherical, surrounded by a distinct nuclear membrane and measures $4 \mu$ to $5.5 \mu$ in diameter. Verma (1969) has reported the interphase nucleus $4.5 \mu$ to $6 \mu$. It contains one to two distinct nucleoli (Fig. $2 \mathrm{a}$ and $2 \mathrm{~b}$ ) and one to two prominent chromocentre-like bodies. At prophase the nucleus becomes double of its original size and the nucleoli gradually disappear. The chromosome threads are visible within whole nuclear cavity (Fig. 2c) and become distinct in late prophase. At metaphase, a count of 12 chromosomes has been determined in the present analysis (Fig. 2d and 2e). The chromosomes have been measured $1.1 \mu$ to $2.2 \mu$ in length and 0.6 to $0.9 \mu$ in breadth.

The chromosome is short, thick and rod-shaped with median and submedian centromeres. The division is synchronous. The anaphase (Fig. 2f) and telophase follow a normal course.

b. Meiosis: Meiosis has been observed within the terminal cells of filaments. The division is synchronous (Fig. 3c). Diplotene and diakinesis stages are very frequent. A count of 6 distinct bivalents has been determined at diakinesis stage 
in the present species. (Fig. 3a and 3b).

All the bivalents usually remain oriented at the equatorial plane of the spindle. The number of chiasmata in the bivalents is found two to four. At first anaphase, the chromosomes of the bivalents become separated from one another, and the positions of centromeres (median or submedian) are seen clearly in some chromosomes. The rest of stage follows a normal course.

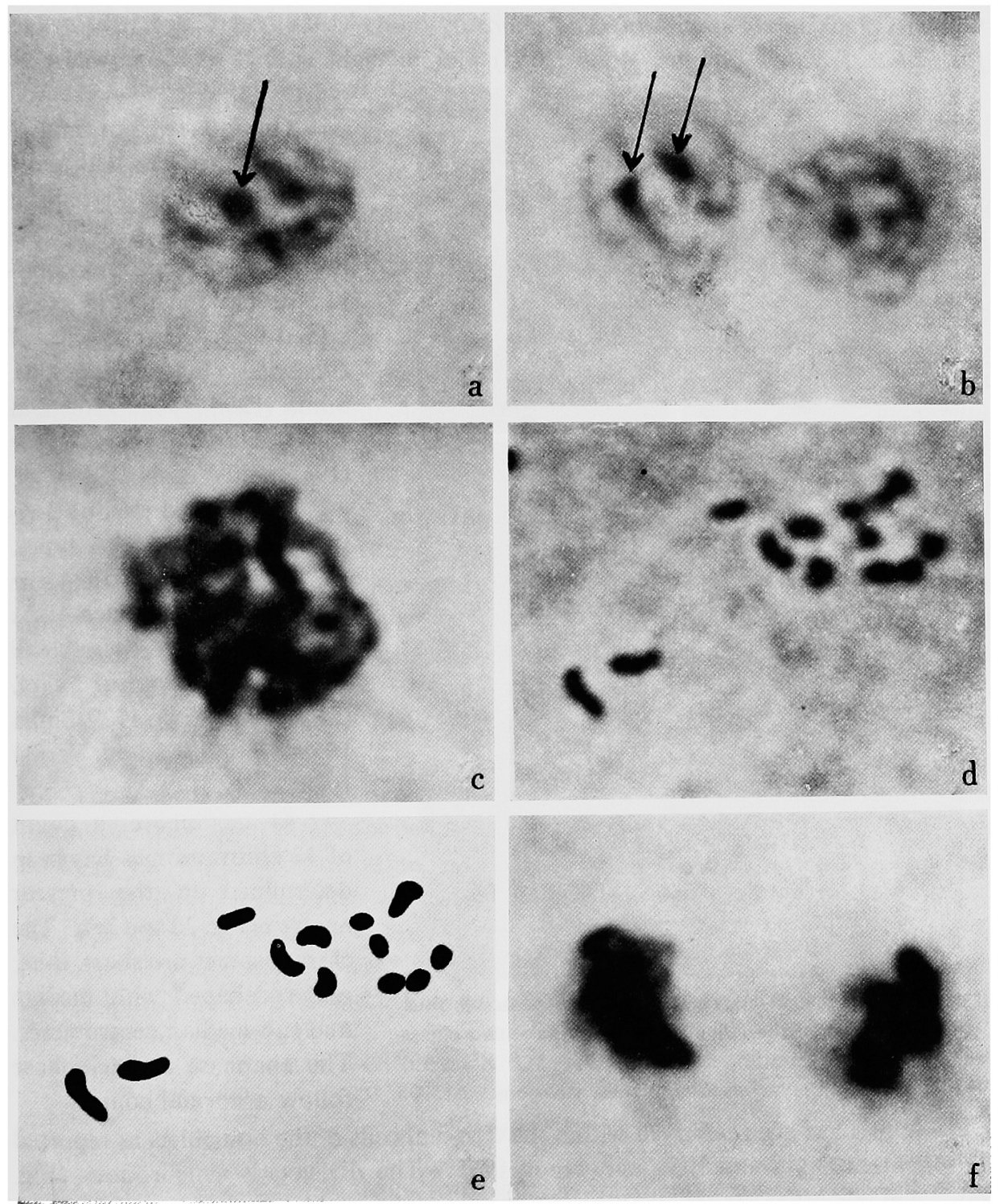

Fig. 2. a, an interphase nucleus showing one nucleolus marked by an arrow. b, an interphase nucleus showing two nuceloli marked by arrows. c, a mid-prophase stage showing condensation of chromsomes. d, a mitotic metaphase plate showing $2 \mathrm{n}=12$ chromosomes. e, outline drawing of Fig. 2d showing 12 mitotic chromosomes. f, a late anaphase stage. All $\times 2875$. 


\section{Discussion}

The interphase nucleus is spherical and appears to be rich in chromatin materials (cf. Geitler 1936, Sinha 1958, 1963 and 1965, Noor 1965 and Verma 1969). One to two nucleoli are found within the interphase nucleus (Fig. 2a and 2b) whereas different numbers of nucleoli have been ascertained in different species of Cladophora as reported in C. flavescens by Higgins (1930), in some forms of Cladophora by Geitler (1936), in six species of Cladophora by Sinha (1958), in C. glomerata var. fasciculata f. fasciculata by Noor (1965) and in eight species of Cladophora by
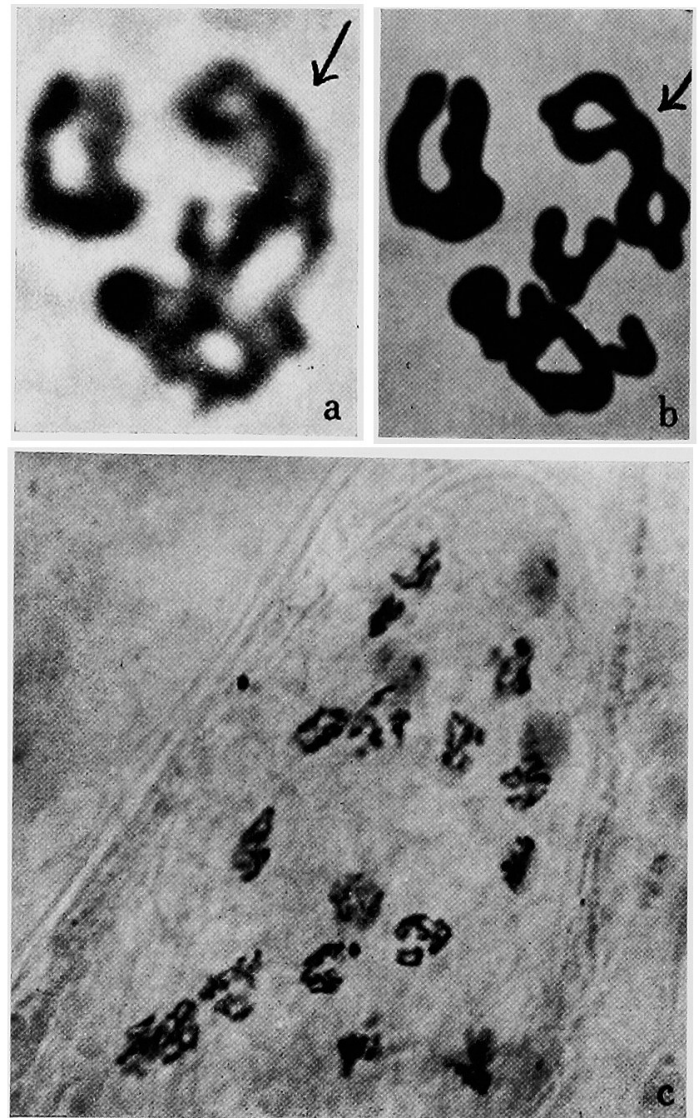

Fig. 3. a, a vivalent marked by an arrow possesses four chiasmata whereas the rest five bivalents have two chiasmata $\times 7410$. b, outline drawing of Fig. 3a. c, several nuclei undergoing synchronous meiotic divisions. $\times 1500$.
Verma (1969).

One to two prominent chromocentre-like bodies are found within the interphase nucleus whereas different numbers of chromocentrelike bodies have been ascertained in different species of Cladophora by Geitler (1936), Sinha (1958, 1963, 1965 and 1968), Schüssnig (1954), Noor (1965) and Verma (1969).

Mitotic and meiotic divisions are of normal types. At mitotic prophase, the nucleus increases twice of its original size and nucleoli gradually disappear (cf. Carter 1919, Foÿn 1929, Sinha 1958, Noor 1965 and Verma 1969).

At metaphase, a count of 12 chromosomes has been determined in the present analysis (Fig. $2 \mathrm{~d}$ and $2 \mathrm{e}$ ). The chromosomes are short, thick and rodshaped with median and sub-median centromeres. The anaphase and telophase follow a normal course.

Meiosis has been observed within the terminal cells of the branchlets as reported by Higgins 1930, Sinha 1958 and Noor 1965. The division is synchronous (Fig. 3c). Among other stages, diakinesis appears to be of longer duration (cf. Sinha 1965) during the first meiotic prophase. Two to four chiasmata are present in the bivalents which resemble with those of higher plants. A count of 6 distinct bivalents have been recorded at diakinesis stage in the present material (Fig. 3a 
and $3 b$ ). These bivalents do not differ from those of higher plants. It is to be pointed out here that Schüssnig (1930) has reported 6 meiotic chromosomes in $C$. suhriana. The present material with $\mathrm{n}=6$ chromosomes is the first record which has not been so far reported in any species of Cladophora from India.

The present finding lends strong support to Geitler's (1936) view that the basic chromosome number in order Cladophorales is 6 and this number has actually been determined in the present species of Cladophora.

The rest of stages follow a normal course.

\section{Life history}

In the light of work done in the past by various workers (cf. T'Serclaes 1922, Cook and Price 1928, Foÿn 1929 and 1934, Czempyrek 1930, List 1930, Higgins 1930, Geitler 1936, Bliding 1936, Schüssnig 1928, 1930, 1938, 1951-54 and 1955, Sinha 1958, 1963 and 1965 and Noor 1965) on different species of Cladophora, there are two types of life-cycles met with in the genus: i) diploid forms ii) forms with isomorphic alternation of generations.

Diploid type of life cycle consists in the occurrence of mitosis preceding zoospore formation as reported by Schüssnig (1928, 1951-54) and List (1930) in C. glomerata. They have further reported the occurrence of meiosis preceding gamete formation in this species.

In the present material, meiosis appears to precede zoospore formation. Formation of gamete has not been observed, however, it is suspected that they are formed preceding mitotic divisions. Thus, the present alga possesses isomorphic alternation of generations. This type of life cycle seems to be widespread in other species of Cladophora as reported by Schüssnig (1930), Foÿn (1929 and 1934) and Sinha (1936 and 1965).

The swarmer formation has been observed within the terminal cells of filaments in basipetal order.

The swarmers are liberated through lateral as well as apical pores. After liberation, they swim inside the neighbouring water for sometime and finally settle down at the rim of culture vessels. They directly germinate into new filaments. It is, thus, inferred that they are presumably zoospores.

The zoospore (Fig. 1c and d) is quadriflagellate and is oval in out line. It possesses a prominent eye-spot just little behind the anterior end. It measures $12.5 \mu$ long and $9.5 \mu$ broad. Similar observations have been made by Verma (1969) for this species.

\section{Summary}

1. The present paper deals with the studies of life-history based upon the cytological features on a fresh-water species of Cladophora viz. C. uberrima Lambert, collected from Ranchi in the month of July 1970.

2. Stages of mitosis as well as of meiosis follow a normal course. 
3. A count of 12 mitotic and 6 meiotic chromosomes has been determined for this species. The meiotic chromosomal count $(n=6)$ determined in this species is the first record from India.

4. The chromosomes show median and sub-median centromeres like most higher plants. The number of chiasmata in the bivalents ranges from two to four.

5. Meiosis precedes quadriflagellate zoospore formation. Formation of gametes has not been observed, however, it is suspected that they are formed preceding mitotic divisions. Thus, the present alga possesses isomorphic alternation of generations, as other species of Cladophora reported by Schüssnig (1930), Foÿn (1929 and 1934) and Sinha (1963 and 1965).

6. Geitler (1936) holds that the basic chromosome number in Order Cladophorales is 6 and this number has actually been determined in the present species of Cladophora, lending support to Geitler's (1936) view.

7. Iron-alum acetocarmine method has been used through out the course of this investigation.

The authors are grateful to the authorities of University Grants' Commission, New Delhi for financing the scheme.

\section{Literature cited}

Bliding, C. 1936. Über die Fortpflanzungskörper einiger marinen Cladophora-Arten. Svensk Botanisk Tidskrift 30: 529-536.

Balakrishnan, M. S. 1961. A cytotaxonomical investigation of Indian members of the Cladophoraceae. Prof. P. Agharkar Commemoration Volume: 34-40.

Carter, N. 1919. The cytology of the cladophoraceae. Ann. Bot. Lond. 33: 467-478.

Cook, W. R. I. and Price, I. R. 1928. The effect of aeration and light on the development of the Zoosporangia in the genus Cladophora. Jour. Roy. Microsc. Soc. 48: 278-282.

Collins, F. S. 1928. The Green Algae of North America, p. 356.

Czempyrek, H. 1930. Beiträg zur Kenntnis der Schwär-Erbildung bei der Gattung Cladopohora. Arch. Protistenk. 72: 433-452.

De Toni, J. B. 1889. Sylloge Algarum. 1: 264-355.

Fritsch, F. E. 1938. The structure and Reproduction of the Algae 1: 229-248. Cambridge Publication.

Foÿn, B. 1929. Vorläufige Mitteilung über die Sexualität und Generationswechsel von Cladopohora und Ulva. Ber. Dtsch. Bot. Ges. 47: 495-506.

- 1934. Lebenszyklus, Cytologie und Sexualität der Chlorophyceae, Cladophora suhriana Kützing. Arch. Protistenk. 83: 1-56.

Geitler, L. 1936. Vergleichende Untersuchungen über den feineren Kern und Chromosomenbau der Cladophoraceen. Planta 35: 530-578.

Godward, M. B. E. 1942. The life cycle of Stigeoclonium amoenum Kütz. New Phytol 41: 293-300.

- 1948. The iron-alum acetocarmine method for algae. Nature 161: 203.

- 1966. The Chromosomes of the Algae. Edward Arnold (Publishers) Ltd. First Edition.

Higgins, E. M. 1930. Reduction division in sp. of Cladophora. Ann. Bot. Lond. 44: 587-592.

List, H. 1930. Die Entwickelungsgeschichte von Cladophora glomerata Kützing. Arch. Protistenk. 72: 453-481.

Noor, M. N. 1965. Ph.D. Thesis, Ranchi University, Ranchi.

Pringsheim, E. G. 1946. Pure Cultures of Algae. Cambridge publication.

Schüssnig, B. 1928. Die Reductionsteilung bei Cladophora glomerata Österr. Bot. Zeits. 57: 62-67. 
- 1930. Das Chromsomenyclus von Cladophora subriana. Österr. Bot. Zeits. 79: 273-277.

- 1938. Der Kernsphasenweschel von Cladophora gracilis. Biol. Gener. 59: 129-144.

- 1951. Der Kernphasenweschel von Cladophora glomerata. Sv. Bot. Tidsk. 45: 597-602.

- 1954. Gonidiogenese, Gametogenese und Meiose bei Cladopohora glomerata (L.) Kutz. Arch. Protistenk. 100: 287-322.

- 1955. Eine apomeiotische Mutante on Cladophora Utriculosa Kuetz. Publ. Staz. Zool. Napali 27: $377-390$.

Sinha, J. P. 1958. Ph.D. Thesis, London University, London.

- 1963. Cytotaxonomical studies on Cladophora flexuosa (Griff.) Harv. a, marine sp. Cytologia 28: $1-11$.

- 1965. Cytotaxonomical studies on Cladophora Hutchinsiae Harve and C. refracta Aresch, two marine spp. Cytologia 30: 375-384.

- 1968. Cytotaxonomical studies on Cladophora glomerata, Four Freshwater Forms. Cytologia 32: 507-518.

Sinha, J. P. and Noor, M. N. 1967. Chromosome numbers in some members of Chlorophyceae of Chotanagpur. PhyKos. 6: 106.

T'Serclaes, J. 1922. Cytology of Cladophora glomerata. La Cellule 32: 313-326.

Verma, B. N. 1969, Ph.D. Thesis, Ranchi University, Ranchi. 